\title{
Penyuluhan Pencegahan Dan Penanganan KDRT
}

\author{
Alexander Djuang Papay ${ }^{1 *}$, Rikardo D. Butar-Butar², Yefta Arisma ${ }^{3}$, Budi Bulu \\ Salempang 4 \\ ${ }^{1,4}$ Prodi Studi Teologi, STT Real Batam \\ ${ }^{2,3}$ Prodi Studi PAK, STT Real Batam \\ alexdjuangpapay@gmail.com
}

\begin{abstract}
Violence in household is an act that is carried out in the household by husband, wife, or child, which has a negative impact on physical, psychological integrity and harmonious relationships. There are various forms of violence that occur in households, and it could be that we are experiencing violence without realizing it, or in the households around us. Domestic violence is an act that violates the law because it needs to be prevented. For that every individual needs to know and understand what domestic violence is, what are the factors for the occurrence of domestic violence and how to overcome it.

Keywords: Counseling, Prevention, Handling, Violence, Household
\end{abstract}

\begin{abstract}
Abstrak
Kekerasan dalam rumah tangga merupakan tindakan yang dilakukan didalam rumah tangga baik oleh suami, istri, maupun anak yang memberi dampak buruk bagi keutuhan fisik, psikis dan keharmonisan hubungan. Ada berbagai bentuk kekerasan yang terjadi dalam rumah tangga, dan bisa saja tanpa disadari kekerasan itu sedang kita alami, ataupun rumah tangga disekitar kita. Kekerasan dalam rumah tangga perbuatan yang melanggar hukum karena itu perlu dilakukan pencegahan. Untuk itu setiap individu perlu mengetahui dan memahami apa itu kekerasan dalam rumah tangga, apa yang mejadi faktor-faktor terjadinya kekerasan dalam rumah tangga dan bagaimana menanggulanginya.

Kata Kunci: Penyuluhan, Pencegahan, Penanganan, Kekerasan, Rumah Tangga
\end{abstract}

\section{PENDAHULUAN}

Sebuah keluarga disebut harmonis apabila seluruh anggota keluarga merasa bahagia yang ditandai dengan tidak adanya konflik, ketegangan, kekecewaan dan kepuasan terhadap keadaan (fisik, mental, emosi dan sosial) seluruh anggota keluarga. Keluarga disebut disharmonis apabila terjadi sebaliknya. Ketegangan maupun konflik antara suami dan istri maupun orang tua dengan anak merupakan hal yang wajar dalam sebuah keluarga atau rumah tangga. Tidak ada rumah tangga yang berjalan tanpa konflik namun konflik dalam rumah tangga bukanlah sesuatu yang menakutkan. Hampir semua keluarga pernah mengalaminya. Yang mejadi berbeda adalah bagaimana cara mengatasi dan menyelesaikan hal tersebut

Setiap keluarga tentu memiliki cara untuk menyelesaikan masalahnya masing-masing. Apabila masalah diselesaikan secara baik dan sehat maka setiap anggota keluarga akan mendapatkan pelajaran yang berharga yaitu menyadari dan mengerti perasaan, kepribadian dan pengendalian emosi tiap anggota keluarga sehingga terwujudlah kebahagiaan dalam keluarga. Penyelesaian konflik secara sehat terjadi bila masing-masing anggota keluarga tidak mengedepankan kepentingan pribadi, mencari akar permasalahan dan membuat solusi yang sama-sama menguntungkan anggota keluarga melalui komunikasi yang baik dan lancar. Disisi lain, apabila konflik diselesaikan secara tidak sehat maka konflik akan semakin sering terjadi dalam keluarga.

Kekerasan dalam rumah tangga (KDRT) adalah semua perilaku ancaman, pelecehan, dan kekerasan baik secara fisik, psikologis, dan seksual antara dua orang yang terikat hubungan personal ataupun kepada anggota keluarga lain. Ini artinya, KDRT tidak hanya identik dengan kekerasan secara fisik, tetapi juga bentuk-bentuk pelecehan lainnya yang merugikan korban. Adapun korban dan pelakunya bisa siapapun, yaitu suami, istri, anak, atau orang-orang yang mempunyai hubungan dengan orang tersebut di dalam rumah yang sama. 


\section{METODE}

Kegiatan PkM ini dilakukan dengan menggunakan metode Ceramah sekaligus outing Bersama dengan Jemaat GBI BCS Mall. Jurnal ini disusun dengan menggunakan metode Kualitatif deskriptif analisis dengan mengumpulkan data dalam bentuk catatan dan dikaji secara mendalam guna menemukan penjelasan-penjelasan sedalam-dalamnya. Kegaitan Penyuluhan dilakukan pada tanggal 3 Januari 2018 di Pantai Barelang Batam.

\section{HASIL DAN PEMBAHASAN}

\section{Pengertian Kekerasan dalam Rumah Tangga.}

Kekerasan dalam Rumah Tangga seperti dalam Undang-undang No.23 Tahun 2004 tentang Penghapusan Kekerasan dalam Rumah Tangga, memiliki arti, setiap perbuatan terhadap seseorang terutama perempuan, yang berakibat timbulnya kesengsaraan atau penderitaan secara fisik, seksual, psikologis, dan/atau penelantaran rumah tangga termasuk ancaman untuk melakukan perbuatan, pemaksaan, atau perampasan kemerdekaan secara melawan hukum dalam lingkup rumah tangga. ${ }^{1}$

Tindak kekerasan yang dilakukan suami terhadap isteri sebenarnya merupakan unsur yang berat dalam tindak pidana, dasar hukumnya adalah KUHP (kitab undang-undang hukum pidana) pasal 356 yang secara garis besar isi pasal yang berbunyi:

"Barang siapa yang melakukan penganiayaan terhadap ayah, ibu, isteri atau anak diancam hukuman pidana"

\section{Bentuk-bentuk Kekerasan dalam Rumah Tangga.}

Menurut Undang-Undang No. 23 Tahun 2004 tindak kekerasan terhadap istri dalam rumah tangga dibedakan kedalam 4 (empat) macam :

a. Kekerasan fisik

Kekerasan fisik adalah perbuatan yang mengakibatkan rasa sakit, jatuh sakit atau luka berat. Prilaku kekerasan yang termasuk dalam golongan ini antara lain adalah menampar, memukul, meludahi, menarik rambut (menjambak), menendang, menyudut dengan rokok, memukul/melukai dengan senjata, dan sebagainya. Biasanya perlakuan ini akan nampak seperti bilur-bilur, muka lebam, gigi patah atau bekas luka lainnya.

\section{b. Kekerasan psikologis / emosional}

Kekerasan psikologis atau emosional adalah perbuatan yang mengakibatkan ketakutan, hilangnya rasa percaya diri, hilangnya kemampuan untuk bertindak, rasa tidak berdaya dan / atau penderitaan psikis berat pada seseorang.

Perilaku kekerasan yang termasuk penganiayaan secara emosional adalah penghinaan, komentar-komentar yang menyakitkan atau merendahkan harga diri, mengisolir istri dari dunia luar, mengancam atau ,menakut-nakuti sebagai sarana memaksakan kehendak. ${ }^{3}$

\section{c. Kekerasan seksual}

Kekerasan jenis ini meliputi pengisolasian (menjauhkan) istri dari kebutuhan batinnya, memaksa melakukan hubungan seksual, memaksa selera seksual sendiri, tidak memperhatikan kepuasan pihak istri.Kekerasan seksual berat, berupa:

1. Pelecehan seksual dengan kontak fisik, seperti meraba, menyentuh organ seksual, mencium secara paksa, merangkul serta perbuatan lain yang menimbulkan rasa muak/jijik, terteror, terhina dan merasa dikendalikan.

2. Pemaksaan hubungan seksual tanpa persetujuan korban atau pada saat korban tidak menghendaki.

3. Pemaksaan hubungan seksual dengan cara tidak disukai, merendahkan dan atau menyakitkan.

1 "Undang-Undang No. 23 Tahun 2004 Tentang Penghapusan Kekerasan Dalam Rumah Tangga (UUPKDRT)," Kementrian Hukum Dan Hak Asasi Manusia Republik Indonesia Direktorat Jenderal Peraturan Perundang-Undangan.

${ }^{2}$ Esmi Wrassih, Pranata Hukum : Sebuah Telaah Sosiologis (semarang: Suryandaru Utama, 2005).

${ }^{3}$ Mansour Fakih, Diskriminasi Dan Beban Kerja Perempuan: Perspektif Gender (Yogyakarta: CIDESINDO, 1998). 
4. Pemaksaan hubungan seksual dengan orang lain untuk tujuan pelacuran dan atau tujuan tertentu.

5. Terjadinya hubungan seksual dimana pelaku memanfaatkan posisi ketergantungan korban yang seharusnya dilindungi.

6. Tindakan seksual dengan kekerasan fisik dengan atau tanpa bantuan alat yang menimbulkan sakit, luka, atau cedera. ${ }^{4}$

Kekerasan Seksual Ringan, berupa pelecehan seksual secara verbal seperti komentar verbal, gurauan porno, siulan, ejekan dan julukan dan atau secara non verbal, seperti ekspresi wajah, gerakan tubuh atau pun perbuatan lainnya yang meminta perhatian seksual yang tidak dikehendaki korban bersifat melecehkan dan atau menghina korban. Melakukan repitisi kekerasan seksual ringan dapat dimasukkan ke dalam jenis kekerasan seksual berat. ${ }^{5}$

\section{d. Kekerasan ekonomi}

Setiap orang dilarang menelantarkan orang dalam lingkup rumah tangganya, padahal menurut hukum yang berlaku baginya atau karena persetujuan atau perjanjian ia wajib memberikan kehidupan, perawatan atau pemeliharaan kepada orang tersebut. Contoh dari kekerasan jenis ini adalah tidak memberi nafkah istri, bahkan menghabiskan uang istri.

Kekerasan Ekonomi Berat, yakni tindakan eksploitasi, manipulasi dan pengendalian lewat sarana ekonomi berupa:

a. Memaksa korban bekerja dengan cara eksploitatif termasuk pelacuran.

b. Melarang korban bekerja tetapi menelantarkannya.

c. Mengambil tanpa sepengetahuan dan tanpa persetujuan korban, merampas dan atau memanipulasi harta benda korban.

Kekerasan Ekonomi Ringan, berupa melakukan upaya-upaya sengaja yang menjadikan korban tergantung atau tidak berdaya secara ekonomi atau tidak terpenuhi kebutuhan dasarnya. ${ }^{6}$

\section{Faktor-faktor penyebab Kekerasan dalam Rumah Tangga}

Adapun yang mengidentifikasi hal dominasi pria dalam konteks struktur masyarakat dan keluarga, yang memungkinkan terjadinya kekerasan dalam rumah tangga sebagai berikut:

a. Pembelaan atas kekuasaan laki-laki

Laki-laki dianggap sebagai superioritas sumber daya dibandingkan dengan wanita, sehingga mampu mengatur dan mengendalikan wanita.

b. Diskriminasi dan pembatasan dibidang ekonomi

Diskriminasi dan pembatasan kesempatan bagi wanita untuk bekerja mengakibatkan wanita (istri) ketergantungan terhadap suami, dan ketika suami kehilangan pekerjaan maka istri mengalami tindakan kekerasan.

c. Beban pengasuhan anak

Istri yang tidak bekerja, menjadikannya menanggung beban sebagai pengasuh anak. Ketika terjadi hal yang tidak diharapkan terhadap anak, maka suami akan menyalah-kan istri sehingga tejadi kekerasan dalam rumah tangga.

d. Wanita sebagai anak-anak

Konsep wanita sebagai hak milik bagi laki-laki menurut hukum, mengakibatkan kele-luasaan laki-laki untuk mengatur dan mengendalikan segala hak dan kewajiban wanita. Laki-laki merasa punya hak untuk melakukan kekerasan sebagai seorang bapak melakukan kekerasan terhadap anaknya agar menjadi tertib.

\footnotetext{
${ }^{4}$ Utomo Brief, Kekerasan Terhadap Perempuan (Jakarta: PT. Indo.Indd, 2009).

${ }^{5}$ C F G Sunaryati Hartono, Politik Hukum Menuju Satu Sistem Hukum Nasional (Bandung: Penerbit Alumni, 1991).

${ }^{6}$ Arief Budiman, Pembagian Kerja Secara Seksual: Sebuah Pembahasan Sosiologis Tentang Peran Wanita Di Dalam Masyarakat (Jakarta: Gramedia, 1981).
} 


\section{e. Orientasi peradilan pidana pada laki-laki}

Posisi wanita sebagai istri di dalam rumah tangga yang mengalami kekerasan oleh suaminya, diterima sebagai pelanggaran hukum, sehingga penyelesaian kasusnya sering ditunda atau ditutup. Alasan yang lazim dikemukakan oleh penegak hukum yaitu adanya legitimasi hukum bagi suami melakukan kekerasan sepanjang bertindak dalam konteks harmoni keluarga.

\section{Cara Penanggulangan Kekerasan dalam Rumah Tangga}

Agar Kekerasan dalam Rumah Tangga, tidak terjadi maka diperlukan cara-cara yang benar dalam penanggulangannya, antara lain:

a. $\quad$ Perlunya keimanan yang kuat dan moral yang baik serta berpegang teguh pada Firman Tuhan sehingga Kekerasan dalam rumah tangga tidak terjadi dan dapat diatasi dengan baik dan penuh kesabaran.

b. Harus tercipta kerukunan dan kedamaian di dalam sebuah keluarga, karena didalam agama itu mengajarkan tentang kasih sayang terhadap ibu, bapak, saudara, dan orang lain. Sehingga antara anggota keluarga dapat saling mengahargai setiap pendapat yang ada.

c. Harus adanya komunikasi yang baik antara suami dan istri, agar tercipta sebuah rumah tangga yang rukun dan harmonis. Jika di dalam sebuah rumah tangga tidak ada keharmonisan dan kerukunan diantara kedua belah pihak, itu juga bisa menjadi pemicu timbulnya kekerasan dalam rumah tangga.

d. Butuh rasa saling percaya, pengertian, saling menghargai dan sebagainya antar anggota keluarga. Sehingga rumah tangga dilandasi dengan rasa saling percaya. Jika sudah ada rasa saling percaya, maka mudah bagi kita untuk melakukan aktivitas. Jika tidak ada rasa kepercayaan maka yang timbul adalah sifat cemburu yang kadang berlebih dan rasa curiga yang kadang juga berlebih-lebihan.

e. Seorang istri harus mampu mengkoordinir berapapun keuangan yang ada dalam keluarga, sehingga seorang istri dapat mengatasi apabila terjadi pendapatan yang minim, sehingga kekurangan ekonomi dalam keluarga dapat diatasi dengan baik. ${ }^{7}$

Selain itu untuk menghindari terjadinya kekerasan dalam rumah tangga tentunya sebelum membangun rumah tangga setiap pasangan sudah mempersiapkan diri dengan baik, dewasa dalam pemikiran dan memiliki kesadaran hukum. Karena itu setiap rumah tangga perlu diberikan edukasi atau penyuluhan yang agar dapat mencegah terjadinya kekerasan dalam rumah tangga.

Walker dalam Nisa, menyatakan latar belakang pendidikan yang tinggi tidak dapat menjadi jaminan bahwa tidak terjadinya kekerasan dalam rumah tangga. Hal itu dapat terjadi kepada siapa saja tanpa dibatasi oleh usia, jenis kelamin, suku bangsa, budaya, agama, jenjang pendidikan, pekerjaan, dan status pernikahan. Nisa juga berpendapat bahwa kekerasan dalam rumah tangga tidak dipengaruhi oleh tinggi rendahnya pendidikan ataupun dipicu oleh situasi ekonomi sesorang, melainkan karena adanya ketidak setaraan antara kekuasaan laki-laki dengan perempuan. ${ }^{8}$

Namun sekalipun kekerasan dalam rumah tangga tidak dibatasi oleh jenis kelamin, Huriyani berpendapat bahwa kekerasan rumah tangga justru lebih rentan dialami oleh pihak perempuan. Hal itu dipengaruhi oleh budaya yang sudah terbentuk dari sejak dulu kala antara laki-laku dan perempuan. Dimana, laki-laki memiliki peranan sebagai pemilik kuasa. Selain itu di Indonesia secara kompleks terbangun beberapa alasan lain. Yaitu: laki-laki lebih unggul secara fisik, tradisi yang mendominasi laki-laki dibandignkan perempuan, realitas ekonomi, faktor psikologi dan perbedaan kekuatan ataupun kekuasaan. ${ }^{9}$

Sakina berpendapat bahwa berbagai kasus kekerasan dalam rumah tangga berkaitan dengan budaya yang melekat yaitu budaya yang bersifat patriarki. Terkhususnya Indonesia, Sakina berpendapat bahwa patriarki merupakan ptoret budaya yang masih melekat pada kebudayaannya. ${ }^{10}$

Susanto mengutip Bressler yang menyatakan Patriarki adalah sebuah sistem sosial

\footnotetext{
${ }^{7}$ Yoga Aditama, Pedoman Pengendalian Kekerasan Dalam Rumah Tangga (KDRT) (Jakarta: Erlangga, 2012).

${ }^{8}$ Haiyun Nisa, "Gambaran Bentuk Kekerasan Dalam Rumah Tangga Yang Dialami Perempuan Penyintas," Gender Equality: International Journal of Child and Gender Studies 4, no. 2 (2018): 57-66.60

${ }^{9}$ Yeni Huriyani, "Kekerasan Dalam Rumah Tangga (KDRT): Persoalan Privat Yang Menjadi Persoalan Publik.," Jurnal Legislasi Indonesia 5, no. 3 (2008): 75-86.77-78

${ }^{10}$ Ade Irma Sakina and Dessy Hasanah Siti A., "Menyoroti Budaya Patriarki Di Indonesia," Share : Social Work Journal 7, no. 1 (2017): 71.73
} 
yang menempatkan laki-laki sebagai sosok otoritas utama yang sentral dalam organisasi sosial. Seorang Bapak memiliki kewenangan penuh pada perempuan, anak-anaknya dan juga harta benda yang dimiliknya. Sistem ini memberikan pengaruh pada pemerintahan. Sistem ini juga yang memberikan hak istimewa pada laki-laki dan menempatkan perempuan sebagai kelas dua. Budaya Patriarki memberikan keuntungan dan manfaat bagi laki-laki diberbagai aspek, seperti menentuan garis keturunan yang mengikuti patrilineal eksklusif dengan membawa nama belakang dari laki-laki. Penentuan hak-hak sebagai anak sulung meskipun sebenarnya tidaklah dilahirkan pertama. Pembedaan perlakuan dalam dalam hubungan sosial, serta partisipasi dalam politik. Ataupun juga dalam pembagian tanggung jawab dalam pekerjaan ataupun profesional yang juga ditentukan oleh gender. ${ }^{11}$

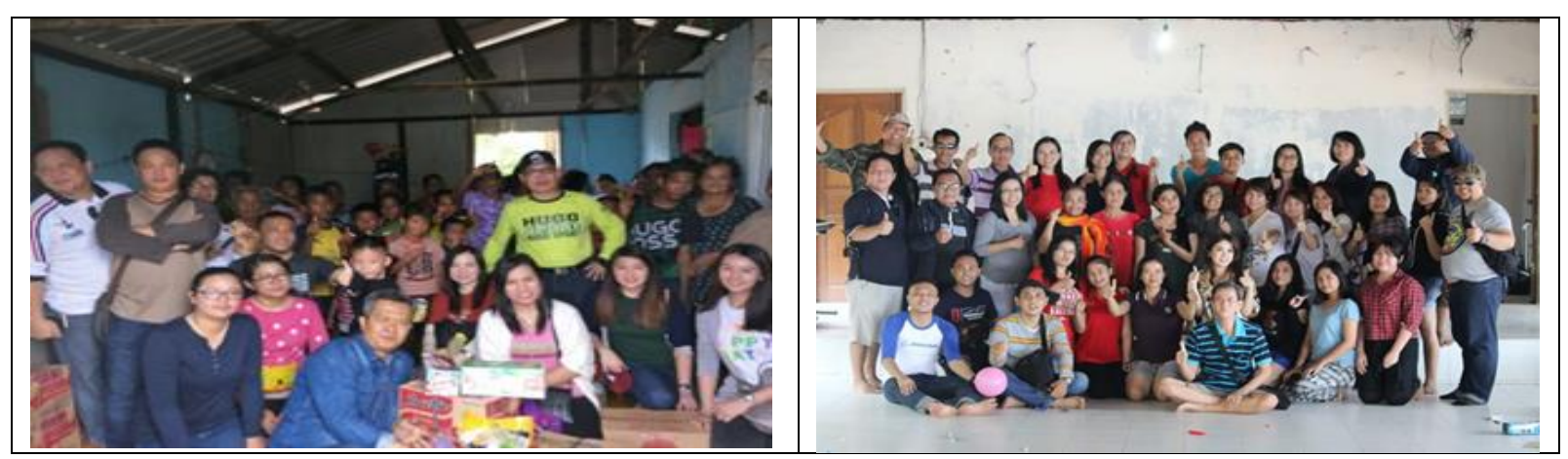

Gambar 1. Foto Setalah Penyuluhan Bersama Jemaat

\section{SIMPULAN}

Isi Kekerasan dalam keluarga merupakan kejahatan. Adanya undang-undang yang tertulis secara khusus untuk rumah tangga, maka orang yang membangun rumah tangga haruslah memiliki kesadaran hukum. Kekerasan dalam rumah tangga dapat terjadi kepada siapa saja tanpa memandang kedudukan dan keadaan ekonomi. Dan kekerasan dalam rumah tangga bukan hanya dalam bentuk tindakan fisik saja, melainkan juga dapat dilihat dari bentuk pelaksanaan tanggung jawab dalam rumah tangga.

Di Indonesia budaya yang sudah terbangun cenderung menjadikan perempuan menjadi pihak yang mengalami kekerasan dalam rumah tangga. Karena kekerasan dalam rumah tangga terjadi karena ketidak setaraannya kekuasaan laki-laki dan perempuan. Maka budaya di Indonesia yang bersifat patriarki cenderung mengakibatkan kekerasan dalam rumah tangga.

\section{DAFTAR PUSTAKA}

Aditama, Yoga. Pedoman Pengendalian Kekerasan Dalam Rumah Tangga (KDRT). Jakarta: Erlangga, 2012.

Brief, Utomo. Kekerasan Terhadap Perempuan. Jakarta: PT. Indo.Indd, 2009.

Budiman, Arief. Pembagian Kerja Secara Seksual: Sebuah Pembahasan Sosiologis Tentang Peran Wanita Di Dalam Masyarakat. Jakarta: Gramedia, 1981.

Fakih, Mansour. Diskriminasi Dan Beban Kerja Perempuan: Perspektif Gender. Yogyakarta: CIDESINDO, 1998.

Hartono, C F G Sunaryati. Politik Hukum Menuju Satu Sistem Hukum Nasional. Bandung: Penerbit Alumni, 1991.

Huriyani, Yeni. "Kekerasan Dalam Rumah Tangga (KDRT): Persoalan Privat Yang Menjadi Persoalan Publik." Jurnal Legislasi Indonesia 5, no. 3 (2008): 75-86.

Nisa, Haiyun. "Gambaran Bentuk Kekerasan Dalam Rumah Tangga Yang Dialami Perempuan Penyintas." Gender Equality: International Journal of Child and Gender Studies 4, no. 2 (2018): $57-66$.

\footnotetext{
${ }^{11}$ Nanang Hasan Susanto, "Tantangan Mewujudkan Kesetaraan Gender Dalam Budaya Patriarki," Jurnal Muwazah 7, no. 2 (2015): 120-130.
} 
Sakina, Ade Irma, and Dessy Hasanah Siti A. "Menyoroti Budaya Patriarki Di Indonesia." Share: Social Work Journal 7, no. 1 (2017): 71.

Susanto, Nanang Hasan. "Tantangan Mewujudkan Kesetaraan Gender Dalam Budaya Patriarki." Jurnal Muwazah 7, no. 2 (2015): 120-130.

Wrassih, Esmi. Pranata Hukum: Sebuah Telaah Sosiologis. semarang: Suryandaru Utama, 2005.

"UNDANG-UNDANG NO. 23 TAHUN 2004 TENTANG PENGHAPUSAN KEKERASAN

DALAM RUMAH TANGGA (UU-PKDRT)." Kementrian Hukum Dan Hak Asasi Manusia Republik Indonesia Direktorat Jenderal Peraturan Perundang-Undangan. 